\title{
Sustainable enhancement of district heating and cooling configurations by combining thermal energy storage and life cycle assessment
}

\author{
Silvia Guillén-Lambea ${ }^{1,2}$, Monica Carvalho ${ }^{3 *}$, Monica Delgado ${ }^{1,2}$, Ana Lazaro ${ }^{2}$ \\ ${ }^{1}$ University Center of Defense, Ctra. Huesca, s/n, 50090, Zaragoza, Spain. \\ ${ }^{2}$ Aragón Institute for Engineering Research (I3A), Thermal Engineering and Energy Systems \\ Group (GITSE), University of Zaragoza, Agustín Betancourt Building, C/María de Luna 3, \\ 50018 Zaragoza, Spain \\ ${ }^{3}$ Department of Renewable Energy Engineering, Federal University of Paraíba, Campus I. \\ Cidade Universitária, s/n - Castelo Branco - João Pessoa - Paraíba - 58051-970, Brazil. \\ * Corresponding author: e-mail: monica@cear.ufpb.br
}

\begin{abstract}
Silvia Guillén-Lambea ORCID: 0000-0003-3269-023X
Mónica Carvalho ORCID: 0000-0002-8524-3452

Mónica Delgado ORCID:0000-0002-8015-4469

Ana Lázaro ORCID: 0000-0001-7360-4188
\end{abstract}

\begin{abstract}
District heating and cooling systems are designed and optimized to respond to the latest challenges of reducing energy demands while fulfilling comfort standards. Thermal energy storage (TES) with phase change materials (PCMs) can be employed to reduce the energy demands of buildings. This study considers a residential district located in Spain, where a general framework has been established to identify optimal combinations of energy conversion, delivery technologies, and operating rules. The life cycle assessment methodology was implemented within a mathematical model, and the objective function considered the minimization of environmental loads. Two environmental impact assessment methods were applied within the LCA methodology: IPCC 2013 GWP 100y and ReCiPe. Four optimal configurations were considered: a reference system (gas boiler, and split-type air conditioners) and then three TES-based systems: one sensible (STES, water) and two latent (LTES1 - paraffin emulsion, and LTES2 - sodium acetate trihydrate). Hourly environmental loads associated with electricity imports from the national grid were available. The conventional energy system
\end{abstract}




\section{AUTHOR CONTRIBUTIONS}

All authors contributed to the study conception and methodology. Material preparation, data collection and life cycle assessment were performed by Silvia Guillén-Lambea and Monica Carvalho, thermal energy storage design and phase change material selection were performed by Mónica Delgado, and construction of the mathematical model and its calculations were performed by Ana Lázaro. The first draft of the manuscript was written by Silvia GuillénLambea, and edited and proofread by Monica Carvalho. Finally, all authors contributed to the final version of the manuscript. 


\section{INTRODUCTION}

It is estimated that global energy demands will increase by $80 \%$ by 2050 , with consequent $50 \%$ more greenhouse gas (GHG) emissions primarily due to a $70 \%$ growth in energy-related $\mathrm{CO}_{2}$ emissions (OECD and the PBL Netherlands Environmental Assessment Agency, 2012). Security in the supply of energy and reduced emissions can be achieved through improvement in energy efficiency, energy savings, a higher proportion of renewable energy, and processwide integration.

District heating and cooling systems (DHC) distribute thermal energy to multiple buildings through a network of underground pipes, and the use of thermal energy storage (TES) can provide substantial benefits from economic, energy, and environmental viewpoints (Serra et al., 2009).

District air conditioning systems have been experiencing considerable advances lately, being optimized to respond to the latest challenges of reducing the energy demand of buildings while maintaining the thermal comfort level of residences. Phase change materials (PCMs), for example, can be employed to reduce the heating and cooling demands of buildings. A review of TES with PCMs, including heat transfer analysis and applications, was accomplished by (Zalba et al., 2003). TES using solid-liquid PCMs is a widespread technique because of the high thermal energy storage per unit volume. Currently, the utilization of two-phase materials such as paraffin dispersed in water, results in an effective latent heat storage medium (e.g., PCM emulsions, microencapsulated PCM slurries) (Delgado et al., 2012). Although the use of PCMs is nowadays scientifically developed, there are still environmental unknowns that are a strong motivation for further research.

A generalized environmental conscience has emerged, raising awareness and generating demands for products with enhanced sustainability (Carvalho et al., 2016). However, reductions in environmental impacts can only be achieved after adequate calculations. The life cycle assessment (LCA) is the leading methodology to measure product sustainability, which refers to the environmental negative impacts and benefits in decision-making processes towards more sustainable products throughout their life cycle. Once environmental impacts are quantified, actions can be carried out to reduce this burden.

Important environmental benefits were revealed by an LCA (Raluy et al., 2014) conducted on an energy system with solar thermal energy and seasonal TES using water as storage fluid for air conditioning of a district. PCMs for solar energy storage have been studied and considered efficient from an environmental aspect (López-Sabirón et al., 2014), with the preferred PCMs 
being paraffin, fatty acids, and salt hydrates (Kyriaki et al., 2017). Oró et al. (2012) carried out comparative LCAs for three TES systems for solar plants (solid media, molten salts, and PCM) and concluded that solid media were the most appropriate from an environmental viewpoint. Considering the life cycle performance, PCMs are more environmentally friendly than their reference cases (Kylili and Fokaides, 2016). Gracia et al. (2015) added PCM to a Mediterranean building envelope, and verified a decrease in energy consumption during the operation stage, with an overall $10 \%$ reduction in global impacts. Falco et al. (2017) introduced an innovative storage device, called ColdPeak, which demonstrated unique properties in terms of charging/discharging storage power. The environmental impacts associated with ColdPeak were extremely low due to the amount of energy saved thanks to its application. Cabeza et al. (2014) carried out an LCA of PCMs employed in buildings and obtained high levels of embedded energy within PCMs. It is therefore not straightforward to affirm that the (higher) impacts associated with manufacture are compensated by reductions in the operational impacts, which was also the conclusion of Miró et al. (2015). The "Speicher-LCA" project assessed the environmental performance of a variety of innovative materials available for energy storage in buildings, as presented by Horn et al. (2018). Nienborg et al. (2018) verified that PCM could be environmentally beneficial compared to water if used in an application with a small useful temperature difference (e.g., cooling). Adeoye et al. (2013) developed a comparative LCA of two thermal energy storage systems for a concentrated solar power plant, and verified that molten salt TES halves the environmental impacts in comparison with concrete TES. However, the quantification of environmental impacts in DHC systems remains underexplored (Bartolozzi et al., 2017), especially regarding latent heat storage.

A general framework has been established a priori (Pina et al., 2018a, 2018b) to identify optimal combinations of energy conversion and delivery technologies, as well as operating rules for the systems. The framework was utilized herein to optimize four scenarios of an energy system that meets the thermal energy demands (space heating, hot water, and cooling) of a residential district (500 units). The objective function considered was the minimization of environmental loads.

The environmental loads associated with four optimal district energy systems were calculated and compared: a conventional system constituted of a gas boiler and air conditioning units for each residential unit, and three TES-based DHC systems, constituted of reversible heat pumps, a photovoltaic solar field (PV panels), and thermal storage tanks (water, paraffin emulsion, and sodium acetate trihydrate). 
Table 1 Annual energy demands for the selected district

\begin{tabular}{ccc}
\hline & Total demand & Peak demand \\
\hline Space heating & $2,397.5 \mathrm{MWh} / 47.9 \mathrm{kWh} / \mathrm{m}^{2}$ & \multirow{2}{*}{$1,876.1 \mathrm{~kW}$} \\
\hline Hot water & $507.5 \mathrm{MWh} / 10.1 \mathrm{kWh} / \mathrm{m}^{2}$ & \\
\hline Cooling & $973.2 \mathrm{MWh} / 19.5 \mathrm{kWh} / \mathrm{m}^{2}$ & $2,285.8 \mathrm{~kW}$ \\
\hline
\end{tabular}

The district energy systems were modeled in Lingo software version 11 (Lindo Systems, 2011), which provides a completely integrated package for the solution of optimization models. The solution of the optimization model yielded an energy system (configuration and operation) with minimum GHG emissions that meet the thermal energy demands of the district system.

The model was solved considering conventional equipment (gas boiler for heating and splittype air conditioners = "reference system") and then considering less routinely deployed technologies: one sensible thermal energy system = "STES", and two latent thermal energy systems = "LTES1" and "LTES2".

The optimization model compares all combinations of energy conversion and delivery technologies, on an hourly basis, to establish the optimal solution, which encompasses the equipment to be installed and its operation throughout the year. Gas boilers, heat pumps, and energy storage are available to satisfy the heating demands, while electricity can be supplied 
by the electric grid or by the photovoltaic (PV) panels. The physical models are based on real operation performance data provided by manufacturers: the efficiency of the gas boilers ( $\eta_{\text {boiler }}$ ) is 0.9 , and the coefficient of performance (COP) and heating capacity of the heat pumps vary with the outlet temperature of the condenser. The energy efficiency ratio (EER) and the cooling capacity vary with the evaporator's outlet temperature. For the PV panels, the nominal power of each panel $\left(P_{\max }\right)$ is $245 \mathrm{~W}$, and the efficiency $\left(\eta_{\text {panel }}\right)$ is $16.1 \%$.

Table 2 shows the equipment selected for each configuration. The technical specifications for the gas boiler, reversible heat pump, air conditioning units, and PV panels were obtained in consultation with manufacturers. Auxiliary equipment, such as pumps and pipes, were not included in the study because they are common to all configurations.

Table 2 Equipment selected for the different configurations.

\begin{tabular}{|c|c|c|c|c|c|}
\hline System & $\begin{array}{c}\text { Heating } \\
\text { equipment }\end{array}$ & $\begin{array}{l}\text { Cooling } \\
\text { equipment }\end{array}$ & $\begin{array}{l}\text { Auxiliary } \\
\text { equipment }\end{array}$ & Storage tank & $\begin{array}{c}\text { Thermal storage } \\
\text { medium }\end{array}$ \\
\hline Reference & $\begin{array}{l}\text { Gas boiler } \\
2,360 \mathrm{~kW}\end{array}$ & $\begin{array}{l}500 \text { split-type } \\
\mathrm{a} / \mathrm{c}, 4.75 \mathrm{~kW} \\
\text { each }\end{array}$ & - & - & - \\
\hline STES & \multirow{3}{*}{$\begin{array}{c}\text { Reversible } \\
\text { heat pump: } \\
1,766 \mathrm{~kW}\end{array}$} & \multirow{3}{*}{$\begin{array}{c}\text { Reversible } \\
\text { heat pump: } \\
1,365 \mathrm{~kW}\end{array}$} & \multirow{3}{*}{$\begin{array}{l}\text { Solar field: } \\
\text { PV panels } \\
3,200 \mathrm{~m}^{2}\end{array}$} & $\begin{array}{c}\text { Cylindrical, } \\
\text { reinforced } \\
\text { concrete } \\
118.6 \mathrm{~m}^{3}\end{array}$ & $\begin{array}{c}\text { Water at } \\
30^{\circ} \mathrm{C} \text { to } 65^{\circ} \mathrm{C}\end{array}$ \\
\hline LTES1 & & & & $\begin{array}{c}\text { Cylindrical } \\
\text { insulated } \\
\text { stainless steel } \\
145.0 \mathrm{~m}^{3} \\
\text { Mixers } 37.7 \mathrm{~kW}\end{array}$ & $\begin{array}{c}\text { Paraffin at } \\
30^{\circ} \mathrm{C} \text { to } 50^{\circ} \mathrm{C}\end{array}$ \\
\hline LTES2 & & & & $\begin{array}{c}\text { Stainless steel } \\
\text { modules } \\
83.5 \mathrm{~m}^{3}\end{array}$ & $\begin{array}{c}\text { SAT at } \\
30^{\circ} \mathrm{C} \text { to } 58^{\circ} \mathrm{C}\end{array}$ \\
\hline
\end{tabular}

The two different PCMs were selected following the possible operation temperature ranges of the heat pump, and because there is sufficient published data on their thermophysical properties 
and storage systems. The emulsified PCM employed in LTES1 is a low cost paraffin, more specifically a by-product of the petroleum refining process (Delgado et al., 2012). The solids content of this PCM emulsion is approximately $60 \%$, with an average particle size of $1 \mu \mathrm{m}$. Within its melting temperature range $\left(30^{\circ} \mathrm{C}\right.$ to $\left.50{ }^{\circ} \mathrm{C}\right)$, the paraffin emulsion can store 122 $\mathrm{MJ} / \mathrm{m}^{3}$; it must be highlighted that the phase change temperature range is quite extensive, as the PCM is a by-product and has not undergone purification processes (Delgado et al., 2012). Regarding LTES2, the issue of phase separation was taken into account and therefore SAT with Carboxy-Methyl-Cellulose (CMC) as a thickening agent was considered (mass fraction 1\%) (Kong et al., 2019). SAT has a melting point of $58^{\circ} \mathrm{C}$, relatively high melting enthalpy at 264 $\mathrm{kJ} / \mathrm{kg}$ (Dannemand et al., 2015), and within its operation temperature, density is between 1.25 $\mathrm{kg} / \mathrm{m}^{3}$ and $1.45 \mathrm{~kg} / \mathrm{m}^{3}$ (Dannemand et al., 2018). Also, SAT presents stable supercooling, and therefore generally reliable mechanisms are required for the controlled initialization of crystallization (Englmair et al., 2018a).

The solution of the optimization model provided the storage capacity, which must be $4,820 \mathrm{kWh}$ (working at both temperature levels, $60{ }^{\circ} \mathrm{C}$ and $65^{\circ} \mathrm{C}$ ). The water storage tank was designed following (Raluy et al., 2014).

For the design of the paraffin storage tank, geometric similarity has been applied based on a 46 L storage tank successfully tested previously (Delgado et al., 2017), resulting in 29 stainless steel tanks $\left(5 \mathrm{~m}^{3}\right.$ each). A mixer was installed at the upper part of the central axis to improve storage efficiency and promote heat transfer. Herein mixers were sized following geometric similarity and the similarity of Reynolds number. The mixer installed in each storage tank operates at $171 \mathrm{rpm}$ (mechanical power $1.3 \mathrm{~kW}$ ). Considering efficiency and friction losses, a $3.0 \mathrm{~kW}$ motor was selected.

For the design of the SAT storage tank, the segmented heat-storage prototype proposed by Englmair et al. (2018b) was adopted due to the availability of technical specifications. The segmented PCM heat storage is constituted of flat units, which enclose the SAT with CMC. Parallel flow channel heat exchangers are attached on the top and bottom of each flat PCM container. As aforementioned, crystallization triggering is required, which is accomplished utilizing an activation device mounted on a flange of the air expansion chamber of each PCM unit. Using this device, solid SAT crystals are added to the supercooled SAT. Each PCM unit also counts with an expansion vessel. According to the phase change enthalpy of SAT with CMC, considering its density and assuming a $100 \%$ storage efficiency, 446 PCM units are required to meet the storage capacity requirements $(4,820 \mathrm{kWh})$. 
Electricity could be imported from the electric grid, and its hourly GHG emissions were also available, indicating the temporal nature of the emissions.

\subsection{Life cycle assessment}

Life Cycle Assessment (LCA) is a validated and consolidated methodology for the quantification of environmental impacts throughout the life cycle of a product, process or activity (Guinée et al., 2001). LCA has been standardized by the International Organization for Standardization (ISO) (2006a, 2006b), and presents four interrelated steps: i) Definition of goal and scope (identification of the object to be analyzed, establish context and system boundaries); ii) Analysis of inventory (identification and quantification of material and energy flows as inputs as well as environmental releases as outputs); iii) Impact assessment (application of an environmental assessment method), and iv) Interpretation (analysis of results, comparison of alternatives). An excellent introduction to LCA can be consulted in (Guinée et al., 2011).

\section{i) Definition of goal and scope}

The aim of this study is to quantify and compare the environmental loads associated with the four district energy systems defined in the previous section. The results will determine if the environmental loads associated with the manufacturing and operation phase of a district air conditioning system, including TES, are sufficiently low in comparison with a more conventional system. Additionally, the evaluation of the environmental impact of the two latent heat storage systems will evaluate if the emissions associated with the operation stage are satisfactorily low to balance out the emissions related to manufacturing the PCMs.

The functional unit considered herein was the energy required to meet the energy demands of the residential district.

\section{ii) Analysis of inventory}

The life cycle inventory (LCI) considers the material composition of the equipment and includes extraction and processing of raw materials, manufacturing, transportation and distribution, use, maintenance, and final disposal. This step focused on the material composition of the equipment for the four energy systems and did not include distribution networks, which are similar across systems. Maintenance, dismantling, recycling, and disposal of equipment have not been included in this research. 
Table 3 presents the main material composition for the equipment, while Table 4 shows the

Table 3 Main material composition per equipment

\begin{tabular}{|c|c|c|c|c|c|c|c|}
\hline Materials (kg) & Gas Boiler & Splits & Heat pump & PV panels & ST Water & ST Paraffin & ST SAT \\
\hline Stainless steel & 589.9 & $4,174.5$ & $13,154.2$ & - & $1,738.6$ & $19,263.9$ & $297,963.0$ \\
\hline Reinforcing steel & - & - & - & - & $43,478.3$ & - & - \\
\hline Steel, low-alloyed & $11,443.4$ & $8,349.0$ & $3,507.9$ & 699.9 & - & - & - \\
\hline Concrete & - & - & - & - & $120,371.4$ & - & - \\
\hline Copper & 589.9 & $4,950.0$ & $3,858.6$ & 822.0 & - & - & - \\
\hline Aluminium & 353.9 & $2,475.0$ & - & 68.7 & - & - & - \\
\hline Brazing solder & 141.6 & - & - & - & - & - & - \\
\hline $\begin{array}{l}\text { Electronic } \\
\text { component }\end{array}$ & - & 275.0 & - & - & - & - & - \\
\hline Lubricating oil & - & - & 298.2 & - & - & - & - \\
\hline Polyethylene & 30.0 & $4,950.0$ & - & 200.5 & - & - & - \\
\hline Polystyrene & - & - & - & - & $5,576.7$ & - & - \\
\hline Polyurethane & - & - & - & - & - & 386.6 & $8,405.3$ \\
\hline Polyvinylchloride & - & - & 175.4 & 29.7 & 297.3 & - & 449.0 \\
\hline Refrigerant R134a & - & - & 542.0 & - & - & - & - \\
\hline R410 & - & $1,650.0$ & - & - & - & - & - \\
\hline $\begin{array}{l}\text { Tube insulation } \\
\text { (elastomere) }\end{array}$ & - & - & $1,753.9$ & - & - & - & - \\
\hline Alkyd paint & 59.0 & - & - & - & - & - & - \\
\hline
\end{tabular}

Table 4 Main material composition by system configuration

\begin{tabular}{lrrrrrrrr}
\hline & \multicolumn{2}{c}{ Reference } & \multicolumn{2}{c}{ STES } & LTES1 & LTES2 \\
\hline Materials & $(\mathrm{kg})$ & $\%$ & $(\mathrm{~kg})$ & $\%$ & $(\mathrm{~kg})$ & $\%$ & $(\mathrm{~kg})$ & $\%$ \\
\hline Stainless steel & $4,764.4$ & $11.9 \%$ & $14,892.8$ & $7.6 \%$ & $32,418.1$ & $72.4 \%$ & $311,117.2$ & $93.2 \%$ \\
\hline Reinforcing steel & - & - & $43,478.3$ & $22.1 \%$ & - & - & - & - \\
\hline Steel, low-alloyed & $19,792.4$ & $49.4 \%$ & $4,207.8$ & $2.1 \%$ & $4,207.8$ & $9.4 \%$ & $4,207.8$ & $1.3 \%$ \\
\hline Concrete & - & - & $120,371.4$ & $61.2 \%$ & - & - & - & - \\
\hline Copper & $5,539.9$ & $13.8 \%$ & $4,680.6$ & $2.4 \%$ & $4,680.6$ & $10.5 \%$ & $4,680.6$ & $1.4 \%$ \\
\hline Aluminium & $2,828.9$ & $7.1 \%$ & 68.7 & $0.0 \%$ & 68.7 & $0.2 \%$ & 68.7 & $0.0 \%$ \\
\hline Brazing solder & 141.6 & $0.4 \%$ & - & - & - & - & - & - \\
\hline Electronic & & & & & - & - & - & - \\
component & 275.0 & $0.7 \%$ & - & - & - & $0.7 \%$ & 298.2 & $0.1 \%$ \\
\hline Lubricating oil & - & - & 298.2 & $0.2 \%$ & 298.2 & $0.1 \%$ \\
\hline Polyethylene & $4,980.0$ & $12.4 \%$ & 200.5 & $0.1 \%$ & 200.5 & $0.4 \%$ & 200.5 & $0.1 \%$ \\
\hline Polystyrene & - & - & $5,576.7$ & $2.8 \%$ & - & - & - & - \\
\hline Polyurethane & - & - & - & - & 386.6 & $0.9 \%$ & $8,405.3$ & $2.5 \%$ \\
\hline Polyvinylchloride & - & - & 502.3 & $0.3 \%$ & 205.1 & $0.5 \%$ & 654.1 & $0.2 \%$ \\
\hline Refrigerant R134a & - & - & 542.0 & $0.3 \%$ & 542.0 & $1.2 \%$ & 542.0 & $0.2 \%$ \\
\hline R410 & $1,650.0$ & $4.1 \%$ & - & - & - & - & - & - \\
\hline $\begin{array}{l}\text { Tube insulation } \\
\text { (elastomere) }\end{array}$ & - & - & $1,753.9$ & $0.9 \%$ & $1,753.9$ & $3.9 \%$ & $1,753.9$ & $0.5 \%$ \\
\hline Alkyd paint & 59.0 & $0.1 \%$ & - & - & - & - & $1,753.9$ & $0.5 \%$ \\
\hline
\end{tabular}




\section{iii) Impact assessment}

The LCA was carried out with SimaPro software v.9.0.0.35 (PRe Consultants, 2018), utilizing the Ecoinvent database ("Ecoinvent," 2018), and two environmental impact assessment methods: IPCC 2013 GWP 100y (“Intergovernmental Panel on Climate Change - IPCC, 2013) and the ReCiPe 2016 method (Huijbregts et al., 2016). The IPCC method converts atmospheric emissions into a common metric $\left(\mathrm{CO}_{2}\right.$-eq) using the conversion factors published in the reports of the IPCC, based on the Global Warming Potential (GWP) of the emissions contemplated, throughout a horizon of 100 years. The ReCiPe method (Endpoint $(\mathrm{H}) \mathrm{V} 1.13)$ was included to broaden environmental considerations in the impact assessment, incorporating relevant environmental burdens into different impact categories that allow the evaluation of damages to human health, ecosystem quality, and resources.

SimaPro was employed to calculate the environmental impacts associated with the different configurations, except for electricity consumption. One of the innovations presented herein is the utilization of hourly environmental data associated with the electricity mix provided by the Spanish grid, which was obtained from the solution of the optimization model. Figure 1 depicts the calculations steps for the proposed methodology.

Fig. 1 Methodology scheme.

The fourth LCA step, iv) Interpretation (analysis of results), is presented in Section 3.

\section{RESULTS AND DISCUSSION}

The annual energy consumptions associated with each configuration, during its operational stage, were obtained from the solution of the optimization model. Table 5 shows the results.

Table 5 Energy flows associated with each energy system (annual values)

\begin{tabular}{crrrr}
\hline & Reference & STES & LTES1 & \multicolumn{2}{l}{ LTES2 } \\
\hline Electricity imported from the grid $(\mathrm{kWh})$ & 51,170 & 746,886 & 656,780 & 637,215 \\
\hline Natural gas $\left(\mathrm{Nm}^{3}\right)$ & 350,207 & - & - & 0 \\
\hline
\end{tabular}




\begin{tabular}{llcrr}
\hline Electricity produced by PV panels (kWh) & - & 607,618 & 601,727 & 601,727 \\
\hline $\begin{array}{c}\text { Electricity consumption of the TES agitation } \\
\text { system (kWh) }\end{array}$ & - & - & 19,565 & 0 \\
\hline Electricity consumption of heat pumps (kWh) & - & $1,220,983$ & $1,048,064$ & $1,048,064$ \\
\hline Electricity consumption of pumps (kWh) & - & 133,520 & 190,878 & 190,878 \\
\hline
\end{tabular}

The total electricity consumption of the latent thermal energy storage systems is slightly lower than the sensible thermal energy storage system. In the case of paraffin, the reduction is $7.1 \%$, with an $8.5 \%$ reduction for SAT. The electricity imported from the grid is reduced by $12.1 \%$ for the paraffin and by $14.7 \%$ for SAT, when compared with STES.

The first environmental analysis was developed regarding carbon emissions. Once data were implemented within SimaPro, the IPCC 2013 GWP 100y method was selected, and results for the carbon emissions associated with each configuration were obtained. Hourly electricity emissions regarding consumption from the national electric grid were obtained from the optimization procedure. These are summarized in Table 6 . The absolute emissions associated with the construction phase were divided by the corresponding lifetimes to obtain annual emissions.

The expected lifetimes considered were: storage tanks 50 years, split-type a/c units 10 years, remaining equipment 20 years. It was assumed that refrigerant $\mathrm{R} 410 \mathrm{~A}$ within each $\mathrm{a} / \mathrm{c}$ unit is replaced every five years. The expected lifetime for paraffin and SAT is 20 years ${ }^{1}$.

Table 6 Annual carbon emissions associated with each energy configuration ( $\mathrm{kg} \mathrm{CO}_{2}$-eq/year)

Carbon emissions ( $\mathrm{kg} \mathrm{CO}_{2}$-eq/year) $\quad$ Reference $\quad$ STES LTES1 LTES2

\begin{tabular}{llrrrr}
\hline Gas boiler & 6,240 & - & - & - \\
Splits & 71,020 & - & - & - \\
Heat pumps & - & 13,950 & 13,950 & 13,950 \\
Construction & Photovoltaics & - & 4,950 & 4,950 & 4,950 \\
& Storage tanks & - & 3,580 & 2,040 & 31,660 \\
PCM & - & - & 3,180 & 5,610
\end{tabular}

\footnotetext{
${ }^{1}$ As these PCMs are still under development, there are no data available concerning the expected lifetime, no standard method to test ageing over time, and durability remains unknown.
} 


\begin{tabular}{clrrrr}
\hline & Electricity & 19,000 & 144,178 & 123,433 & 123,433 \\
& Electricity TES & & & & \\
\multirow{3}{*}{ Operation } & agitation system & - & - & 3,971 & - \\
\cline { 2 - 6 } & Natural gas & $1,110,000$ & - & - & - \\
\hline \multirow{2}{*}{ Total } & & $1,206,260$ & 166,658 & 151,524 & 179,603 \\
\hline
\end{tabular}

The carbon emissions emitted by the equipment of the conventional system are almost four times higher than the TES-based systems. This is mainly due to the single air conditioning units $(45,900$ $\mathrm{kg} \mathrm{CO}$-eq/year) and the refrigerant $\mathrm{R} 410 \mathrm{~A}\left(25,120 \mathrm{~kg} \mathrm{CO}_{2}\right.$-eq/year). Also, the high emissions associated with the consumption of natural gas demonstrate that conventional district systems are not a solution to be taken into account for present and future cities, at least not from the perspective of carbon emissions.

The result obtained for LTES1 with the paraffin emulsion reveals that this configuration is the most environmentally-friendly option, with a reduction of $10 \%$ in carbon emissions in comparison with STES.

The expected lifetime for paraffin was considered 20 years, which is probably a very optimistic value. However, the results show that the impact of PCMs is not as high as expected, and therefore a change of material every five or ten years will only slightly alter the results obtained. When the lifetime of paraffin is four years, the emissions of STES and LTES1 are similar. However, if the lifetime of paraffin is higher than four years, the emissions associated with LTES1 are lower.

Moreover, the results show that for the reference system, $94 \%$ of carbon emissions are produced during the operation phase. When considering thermal energy storage, the percentage of carbon emissions due to the construction phase is much more relevant. Research efforts made to date have succeeded in reducing the operational energy consumption of district thermal systems and, consequently, the associated carbon emissions.

For the less routinely deployed systems analyzed (STES, LTES1, and LTES2), the carbon emissions produced during the construction phase correspond to $13 \%, 16 \%$, and $31 \%$ of the overall environmental impacts, respectively. These values reflect a pressing need to focus investigation works on the environmental impacts associated with the construction of equipment, as these begin to be relevant in the overall life cycle of thermal systems.

The second environmental analysis employed the ReCiPe method. Human health, ecosystems, and resources damage indicators were calculated for the construction phase, and Figure 2 depicts the results obtained for each system configuration. 
Fig. 2 Damage indicators for construction of each system configuration (ReCiPe method, endpoint $\mathrm{H}$ )

The damage indicators of the reference system are much higher than those of the sensible thermal storage system, and human health is the indicator that causes a pronounced difference. The LTES2 system with SAT obtained very unfavorable indicators compared to the other two storage systems. Further investigation of these poor results of LTES2 leads to Table 7, which shows a breakdown of the environmental loads associated with each piece of equipment, storage tank, and PCMs, for the three thermal storage systems. Water (storage fluid) does not appear because its loads are negligible.

The damage indicators obtained for the common equipment are important $(2.56 \mathrm{kPt})$, of which $1.91 \mathrm{kPt}$ are due to the heat pump and $0.65 \mathrm{kPt}$ due to the photovoltaic system. The SAT thermal storage tank obtained high damage indicators $(5.35 \mathrm{kPt})$, demonstrating the need to invest efforts towards the design and optimization of new district thermal equipment from environmental viewpoints. The paraffin storage tank presents similar damage indicators to the water tank (0.37vs. 0.39), although its volume is $22 \%$ higher. The paraffin obtains slightly worse indicators than SAT, although $74 \%$ more paraffin is required for the same thermal storage capacity.

Table 7 Damage indicators for equipment, tanks, and PCM (ReCiPe method, endpoint H)

\begin{tabular}{ccccc}
\hline Category & Human Health & Ecosystems & Resources & Total \\
\hline Units & $(\mathrm{kPt})$ & $(\mathrm{kPt})$ & $(\mathrm{kPt})$ & $(\mathrm{kPt})$ \\
\hline Heat pump + PV panels & 1.40 & 0.40 & 0.76 & 2.56 \\
\hline Storage tank: water & 0.14 & 0.06 & 0.14 & 0.33 \\
\hline Storage tank: paraffin & 0.12 & 0.04 & 0.21 & 0.37 \\
\hline Storage tank: SAT & 1.72 & 0.56 & 3.06 & 5.35 \\
\hline Paraffin & 0.14 & 0.06 & 0.55 & 0.75 \\
\hline SAT & 0.25 & 0.11 & 0.30 & 0.66 \\
\hline
\end{tabular}

The volume of PCM required for the storage of thermal energy affects not only the PCM indicators but also those related to the storage tank. Therefore, it is interesting to analyze the damage indicators associated with the three systems per unit of volume $\left(\mathrm{m}^{3}\right)$ of PCM / water. These values are shown in Table 8. 
Table 8 Damage indicators associated per volume unit of PCM/water (annual values)

\begin{tabular}{ccrrrr}
\hline Category & Volume & Total & Human Health & Ecosystems & Resources \\
\hline Units & $\left(\mathrm{m}^{3}\right)$ & $\left(\mathrm{kPt} / \mathrm{m}^{3}\right)$ & $\left(\mathrm{kPt} / \mathrm{m}^{3}\right)$ & $\left(\mathrm{kPt} / \mathrm{m}^{3}\right)$ & $\left(\mathrm{kPt} / \mathrm{m}^{3}\right)$ \\
\hline Water storage tank & 118.60 & 3.29 & 1.37 & 0.57 & 1.35 \\
\hline Water & 118.60 & $3.5 \mathrm{e}-03$ & $1.7 \mathrm{e}-03$ & $0.7 \mathrm{e}-03$ & $1.1 \mathrm{e}-0.3$ \\
\hline Paraffin storage tank & 145.00 & 2.57 & 0.84 & 0.28 & 1.45 \\
\hline Paraffin & 145.00 & 5.18 & 0.96 & 0.43 & 3.80 \\
\hline SAT storage tank & 83.50 & 64.03 & 20.64 & 6.76 & 36.63 \\
\hline SAT & 83.50 & 7.90 & 2.98 & 1.36 & 3.56 \\
\hline
\end{tabular}

The results show that SAT presents higher damage indicators than paraffin; moreover, the SAT storage tank also has considerable values associated with the damage indicators per unit of volume. It is concluded that the volume of PCM is a critical parameter that should be optimized to minimize the environmental impacts associated with thermal energy storage.

The effects of climate change have not been taken into account neither in the configuration or in the operation of the energy systems proposed herein. This will be the focus of future work by the authors. Due to climate change, heating demands are expected to decrease while cooling demand should increase because of higher external temperatures but also due to more intense solar gains throughout the near future years. Rey-Hernández et al. (2018) estimated the air ambient temperatures for 2020, 2050, and 2080 for Valladolid (Spain), which presents a similar climate to Zaragoza. External air temperature is expected to increase by $1.5^{\circ} \mathrm{C}$ in winter and by $3.0^{\circ} \mathrm{C}$ in summer, between 2020 and 2050 . The meteorological data reported lead to a decrease of $12 \%$ in heating demands while cooling demands increase by $16 \%$ between 2020 and 2050 (Rey-Hernández et al., 2018).

Herein any estimated variations in energy consumption are expected to be fully covered by the proposed systems until 2050. However, cooling energy consumption after 2050 should be studied explicitly at a later stage. Climate change is an essential factor, which should be included in further research to propose new improvements in the sustainability of future cooling systems but also to reduce the cooling load in warm climates. An initial approach to the study of climatic characterization and future trends was carried out by (Abrahao et al., 2017), who verified that maximum temperature presented steep annual increments $\left(p<0.001,0.07^{\circ} \mathrm{C} /\right.$ year). Although (Abrahao et al., 2017) focused on the production of electricity from solar and wind 
resources, climatic characterization and trends are very helpful to establish dynamic energy demands (Silva et al., 2019; Eterna et al., 2018; Silva et al., 2018; Medeiros et al., 2019). The configurations of the proposed energy systems were obtained from the solution of an optimization model, focused on the minimization of environmental loads. As a next step, the life cycle cost analysis of the less routinely deployed technologies should be carried out and compared with a configuration based on conventional equipment, to verify the economic viability of PCM systems.

The study presented herein is a starting point to build upon, and further research should focus on LCA for latent heat storage in thermal systems applications, more precisely in district heating and cooling systems. The reduction of energy demands in the operation phase (consequent reduction of environmental impact) means that the environmental impact associated with the manufacturing phase acquires much more relevance. The research presented herein identifies and stresses urgency regarding the inclusion of LCA criteria in the design of industrial equipment.

This study contributes by outlining the priorities of investigation, development, and demonstration of new concepts and technologies to enhance sustainability and reduce the final consumption of primary energy, considering the life cycle holistically. These priorities include the integration of strategies and technologies to increase energy efficiency, the use of renewable energy and storage, development of new technologies, and demand management systems. Better use of energy resources will result in the protection of local jobs. Furthermore, a decrease in the use of available energy results in a minimization of environmental impacts, which is a benefit to all citizens.

\section{CONCLUSIONS}

This study quantified and compared the environmental loads associated with four optimal energy systems: a conventional system constituted of a gas boiler and air conditioning units for each dwelling, and three TES-based DHC systems, constituted of reversible heat pumps, a thermal storage tank (sensible: with water, and latent, with PCMs: paraffin and SAT) and a photovoltaic solar field. These systems were optimized considering the energy demands of a residential district located in Zaragoza (Spain), with 500 dwellings $\left(100 \mathrm{~m}^{2}\right.$ each).

Two environmental impact assessment methods were applied within the LCA methodology: IPCC 2013 GWP 100y and ReCiPe, which provided a more global perspective. It was verified that a traditional energy system, although optimized, presented the worst performance from 
both environmental viewpoints. The traditional, coventional configuration was penalized by the high consumption of natural gas.

Much lower environmental impacts were obtained when energy integration strategies were employed. The TES-based systems presented $86 \%, 87 \%$, and $85 \%$ lower carbon emissions, for the STES with water and LTES1 and LTES2, respectively, in comparison with the traditional system. Regarding the ReCiPe method, the volume of PCM was identified as a crucial parameter and, therefore, it should be optimized from the early stages of the design of new thermal energy storage systems.

The carbon emissions associated with LTES1 were lower than STES, because the impact of paraffin production was compensated by reductions in energy demands during the operational phase of the DHC system. This is valid when the lifetime of paraffin is higher than four years. The results of the SAT system were strongly affected by the design of the tank, which relied on steel. It must be highlighted that information was obtained from a prototype due to the lack of commercially available data. Therefore it is vital to motivate and encourage the use of methodologies such as LCA in the early design stages of new equipment. More specifically, efforts could be directed to equipment within new optimized systems for thermal energy generation in districts.

When evaluating the LCIA damage indicators, the results confirm than the selected design of the SAT tank is out of range in comparison with paraffin. The overall impacts of LTES1 with paraffin are higher than STES with water, mainly due to the paraffin itself (both storage tanks present similar damage indicators) because of the considerable volume of paraffin required. Further research and additional efforts should be made towards the development and the improvement of PCMs to decrease the environmental impacts associated with the manufacturing phase.

\section{REFERENCES}

Abrahao, R., Peixoto, I.M.B.M., Carvalho, M., 2017. Solar or wind energy for the Brazilian semiarid? - Climatic characterization and future trends, in: Proceedings of the 30th International Conference on Efficiency, Cost, Optimization, Simulation and Environmental Impact of Energy Systems. San Diego.

Adeoye, J.T., Amha, Y.M., Poghosyan, V.H., Torchyan, K., Arafat, H.A., 2013. Comparative LCA of Two Thermal Energy Storage Systems for Shams1 Concentrated Solar Power Plant: Molten Salt vs. Concrete. J. Clean Energy Technol. 2, 274-281. https://doi.org/10.7763/jocet.2014.v2.139 
Bartolozzi, I., Rizzi, F., Frey, M., 2017. Are district heating systems and renewable energy sources always an environmental win-win solution? A life cycle assessment case study in Tuscany, Italy. Renew. Sustain. Energy Rev. 80, 408-420. https://doi.org/10.1016/J.RSER.2017.05.231

Cabeza, L.F., Castell, A., Pérez, G., 2014. Life cycle assessment (LCA) of phase change materials (PCMs) used in buildings. Eco-efficient Constr. Build. Mater. 287-310. https://doi.org/10.1533/9780857097729.2.287

Carvalho, M., de Santana Freire, R., de Brito, A., 2016. Promotion of Sustainability by Quantifying and Reducing the Carbon Footprint: New Practices for Organizations, in: Energy, Transportation and Global Warming. Springer, Cham, pp. 61-72.

Dannemand, M., Delgado, M., Lazaro, A., Penalosa, C., Gundlach, C., Trinderup, C., Johansen, J.B., Moser, C., Schranzhofer, H., Furbo, S., 2018. Porosity and density measurements of sodium acetate trihydrate for thermal energy storage. Appl. Therm. Eng. 131, 707-714. https://doi.org/10.1016/J.APPLTHERMALENG.2017.12.052

Dannemand, M., Schultz, J.M., Johansen, J.B., Furbo, S., 2015. Long term thermal energy storage with stable supercooled sodium acetate trihydrate. Appl. Therm. Eng. 91, 671678. https://doi.org/10.1016/J.APPLTHERMALENG.2015.08.055

Delgado, M., Lázaro, A., Mazo, J., Peñalosa, C., Marín, J.M., Zalba, B., 2017. Experimental analysis of a coiled stirred tank containing a low cost PCM emulsion as a thermal energy storage system. Energy 138, 590-601. https://doi.org/10.1016/J.ENERGY.2017.07.044

Delgado, M., Lázaro, A., Mazo, J., Zalba, B., 2012. Review on phase change material emulsions and microencapsulated phase change material slurries: Materials, heat transfer studies and applications. Renew. Sustain. Energy Rev. 16, 253-273. https://doi.org/10.1016/J.RSER.2011.07.152

Ecoinvent, 2018.

Englmair, G., Jiang, Y., Dannemand, M., Moser, C., Schranzhofer, H., Furbo, S., Fan, J., 2018a. Crystallization by local cooling of supercooled sodium acetate trihydrate composites for long-term heat storage. Energy Build. 180, 159-171. https://doi.org/10.1016/J.ENBUILD.2018.09.035

Englmair, G., Moser, C., Furbo, S., Dannemand, M., Fan, J., 2018b. Design and functionality of a segmented heat-storage prototype utilizing stable supercooling of sodium acetate trihydrate in a solar heating system. Appl. Energy 221, 522-534. https://doi.org/10.1016/J.APENERGY.2018.03.124

Eterna, S., Medeiros, L., Abrahão, R., García-garizábal, I., Peixoto, I.M.B.M., Pereira, L., 2018. 
Assessment of Precipitation Trends in the Sertão Paraibano Mesoregion Avaliação de Tendências de Precipitação na Mesorregião do Sertão Paraibano 344-352.

Falco, M., Capocelli, M., Losito, G., Piemonte, V., 2017. LCA perspective to assess the environmental impact of a novel PCM- based cold storage unit for the civil air conditioning. J. Clean. Prod. 165, 697-704. https://doi.org/10.1016/j.jclepro.2017.07.153

Gamalath, I., Hewage, K., Ruparathna, R., Karunathilake, H., Prabatha, T., Sadiq, R., 2018. Energy rating system for climate conscious operation of multi-unit residential buildings. Clean Technol. Environ. Policy 20, 785-802. https://doi.org/10.1007/s10098-018-1510-x Horn, R., Burr, M., Fröhlich, D., Gschwander, S., Held, M., Lindner, J.P., Munz, G., Nienborg, B., Schossig, P., 2018. Life Cycle Assessment of Innovative Materials for Thermal Energy Storage in Buildings. Procedia CIRP 69, 206-211. https://doi.org/10.1016/j.procir.2017.11.095

Huijbregts, M., Steinmann, Z.J.N., Elshout, P.M.F.M., Stam, G., Verones, F., Vieira, M.D.M., Zijp, M., van Zelm, R., 2016. ReCiPe 2016. Natl. Inst. Public Heal. Environ. 194. https://doi.org/10.1007/s11367-016-1246-y

Intergovernmental Panel on Climate Change - IPCC. Revised supplementary methods and good practice guidance arising from the Kyoto protocol, 2013.

Kong, W., Dannemand, M., Brinkø Berg, J., Fan, J., Englmair, G., Dragsted, J., Furbo, S., 2019. Experimental investigations on phase separation for different heights of sodium acetate water mixtures under different conditions. Appl. Therm. Eng. 148, 796-805. https://doi.org/10.1016/J.APPLTHERMALENG.2018.10.017

Kylili, A., Fokaides, P.A., 2016. Life Cycle Assessment (LCA) of Phase Change Materials (PCMs) for building applications: A review. J. Build. Eng. 6, 133-143. https://doi.org/10.1016/j.jobe.2016.02.008

Kyriaki, E., Konstantinidou, C., Giama, E., Papadopoulos, A.M., 2017. Life cycle analysis (LCA) and life cycle cost analysis (LCCA) of phase change materials (PCM) for thermal applications: A review. Int. J. Energy Res. 1-10. https://doi.org/10.1002/er.3945

Lindo Systems, 2011. Lingo: the modeling language and optimizer.

López-Sabirón, A.M., Royo, P., Ferreira, V.J., Aranda-Usón, A., Ferreira, G., 2014. Carbon footprint of a thermal energy storage system using phase change materials for industrial energy recovery to reduce the fossil fuel consumption. Appl. Energy 135, 616-624. https://doi.org/10.1016/J.APENERGY.2014.08.038

Medeiros, S.E.L., Abrahão, R., Silva, L.P., Silva, W.K.M., 2019. Comparison between observed and estimated data to assess air temperature variability and trends in the Sertão 
Paraibano mesoregion (Brazil). Environ. Monit. Assess. 191, 63.

Miró, L., Oró, E., Boer, D., Cabeza, L.F., 2015. Embodied energy in thermal energy storage (TES) systems for high temperature applications. Appl. Energy 137, 793-799. https://doi.org/10.1016/j.apenergy.2014.06.062

National Institute for Public Health and the Environment. Ministry of Health Welfare and Sport., n.d. LCIA: the ReCiPe model.

Nienborg, B., Gschwander, S., Munz, G., Fröhlich, D., Helling, T., Horn, R., Weinläder, H., Klinker, F., Schossig, P., 2018. Life Cycle Assessment of thermal energy storage materials and components. Energy Procedia 155, 111-120. https://doi.org/10.1016/J.EGYPRO.2018.11.063

OECD and the PBL Netherlands Environmental Assessment Agency, 2012. OECD environmental outlook to 2050: the consequences of inaction. Int. J. Sustain. High. Educ. https://doi.org/10.1108/ijshe.2012.24913caa.010

Oró, E., Gil, A., Gracia, A., Boer, D., Cabeza, L.F., 2012. Comparative life cycle assessment of thermal energy storage systems for solar power plants. Renew. Energy 44, 166-173. https://doi.org/10.1016/j.renene.2012.01.008

Peel, B.L., Finlayson, B.L., McMahon, T. a., 2007. Updated world map of the Koppen-Geiger climate classification.pdf. Hydrol. Earth Syst. Sci. 11, 1633-1644. https://doi.org/10.5194/hess-11-1633-2007

Photovoltaic Geographical Information System (PVGIS). Solar radiation tool. [WWW Document], 2019 URL https://re.jrc.ec.europa.eu/pvg_tools/en/tools.html (accessed 5 apr 2020).

Pina, E.A., Lozano, M.A., Serra, L.M., 2018a. Allocation of economic costs in trigeneration systems at variable load conditions including renewable energy sources and thermal energy storage. Energy 151, 633-646. https://doi.org/10.1016/J.ENERGY.2018.03.083

Pina, E.A., Lozano, M.A., Serra, L.M., 2018b. Thermoeconomic cost allocation in simple trigeneration systems including thermal energy storage. Energy 153, 170-184. https://doi.org/10.1016/J.ENERGY.2018.04.012

PRe Consultants, 2018. SimaPro software.

Raluy, G.R., Serra, L.M., Guadalfajara, M., Lozano, M.A., 2014. Life cycle assessment of central solar heating plants with seasonal storage. Energy Procedia 48, 966-976. https://doi.org/10.1016/j.egypro.2014.02.110

Rey-Hernández, J.M., Yousif, C., Gatt, D., Velasco-Gómez, E., San José-Alonso, J., ReyMartínez, F.J., 2018. Modelling the long-term effect of climate change on a zero energy 
and carbon dioxide building through energy efficiency and renewables. Energy Build. 174, 85-96. https://doi.org/10.1016/J.ENBUILD.2018.06.006

Serra, L.M., Lozano, M.-A., Ramos, J., Ensinas, A. V., Nebra, S.A., 2009. Polygeneration and efficient use of natural resources. Energy 34, 575-586. https://doi.org/10.1016/J.ENERGY.2008.08.013

Silva, L.P., Medeiros, S.E.L., Silva, W.K.M., Abrahão, R., 2018. Tendências climáticas na mesorregião da Mata Paraibana e sua influência na produção de energia fotovoltaica. Enciclopédia Biosf. 15, 90-101. https://doi.org/10.18677/EnciBio

Silva, W.K.M., Freitas, G.P., Coelho Junior, L.M., Pinto, P.A.L.A., Abrahão, R., 2019. Effects of climate change on sugarcane production in the state of Paraíba (Brazil): a panel data approach (1990-2015). Clim. Change 154, 195-209. https://doi.org/10.1007/s10584-01902424-7

Zalba, B., Marín, J.M., Cabeza, L.F., Mehling, H., 2003. Review on thermal energy storage with phase change: materials, heat transfer analysis and applications. Appl. Therm. Eng. 23, 251-283. https://doi.org/10.1016/S1359-4311(02)00192-8 


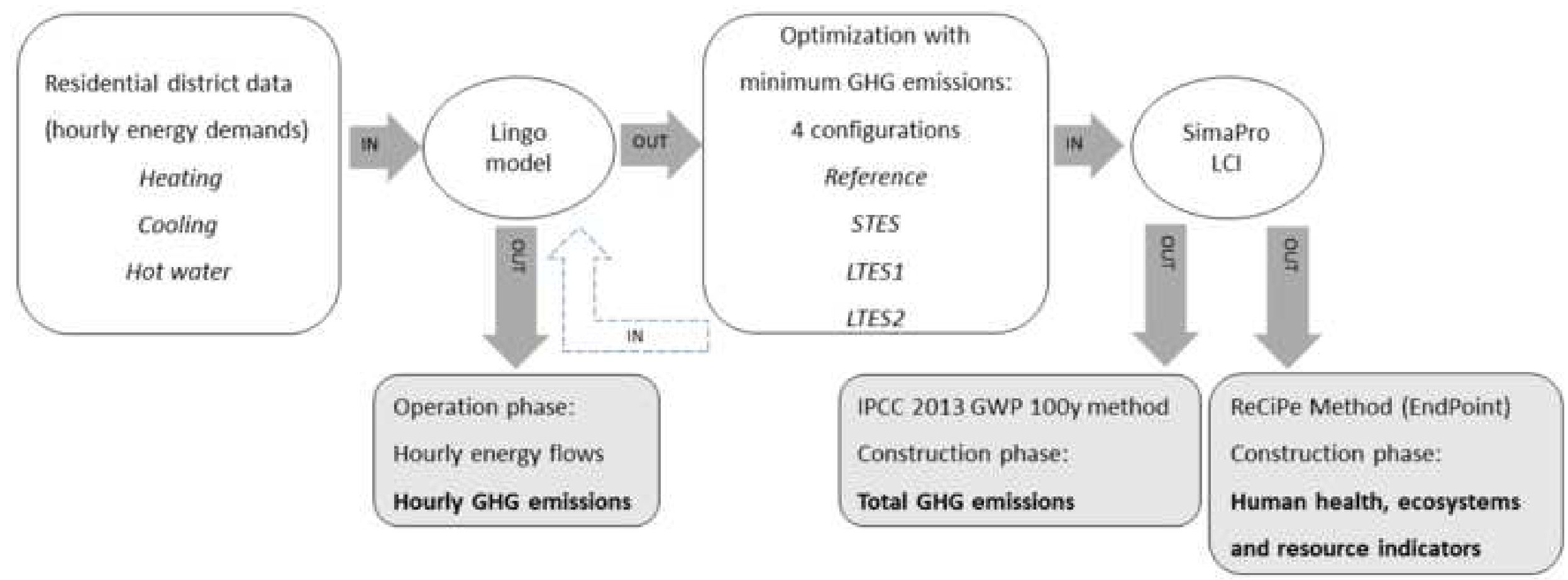

Residential district data

Heating

cooling

Operation phase:

Hourly energy flows

Construction phase:

Total GHG emissions 


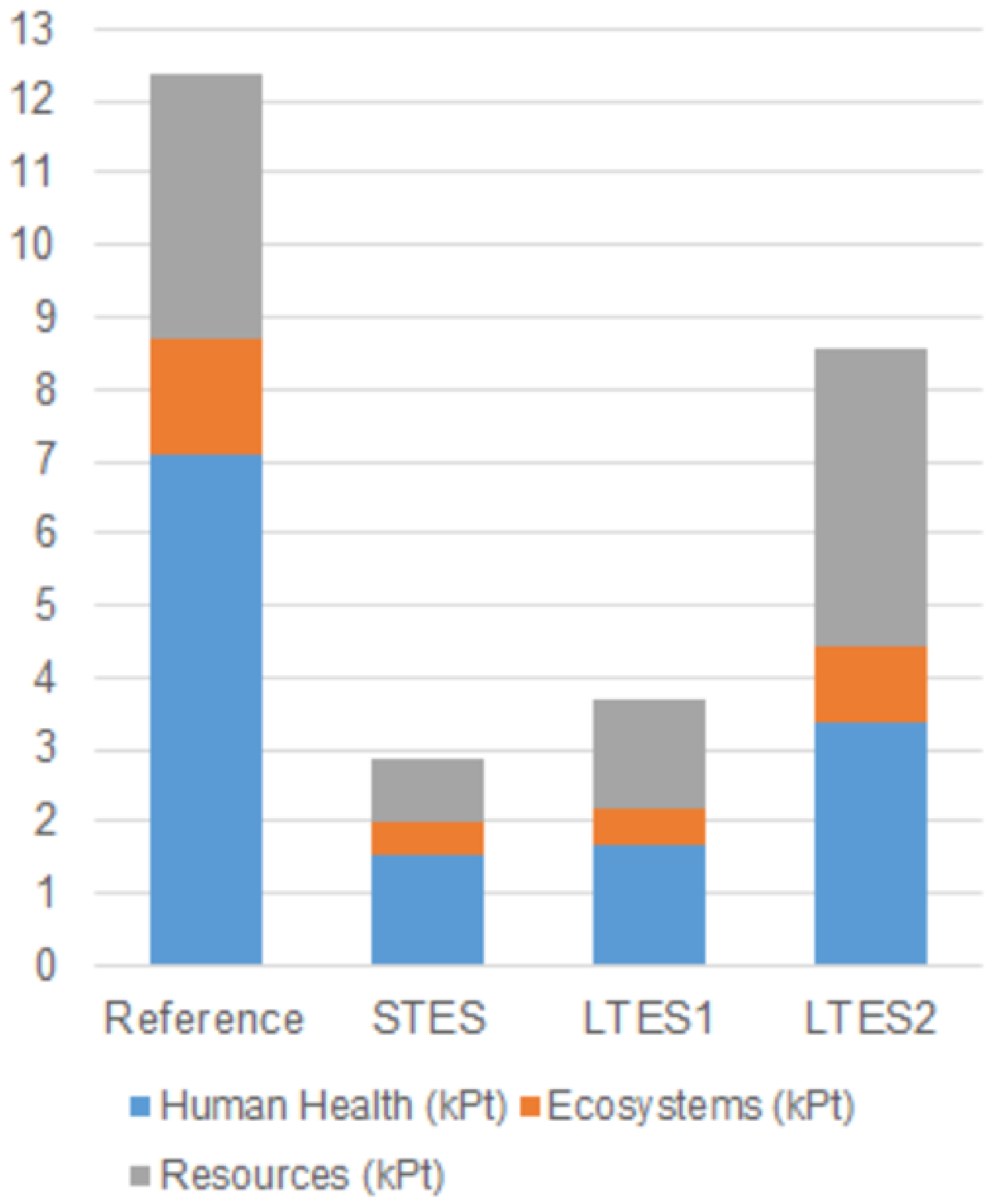


Highlights

Four optimal energy systems are compared from environmental viewpoints via LCA

Conventional energy system is penalized by the high consumption of natural gas

Latent TES with paraffin presented lowest carbon emissions

With ReCiPe method, sensible TES with water presented the lowest burden 


\section{Sustainable enhancement of district heating and cooling configurations by combining Thermal Energy Storage and Life Cycle Assessment}

Type of energy system

Reference system (conventional)

- gas boiler

- split-type air conditioners

Sensible TES system

- reversible heat pumps

- photovoltaic solar field

- thermal storage tanks (water)

Latent TES system 1

- reversible heat pumps

- photovoltaic solar field

- thermal storage tanks (paraffin emulsion)

Sensible TES system 2

- reversible heat pumps

- photovoltaic solar field

- thermal storage tanks (sodium acetate trihydrate)
Annual emissions

$1,206,260 \mathrm{~kg} \mathrm{CO}-$-eq/year

penalized by high censumption of natural gas

$166,658 \mathrm{~kg} \mathrm{CO}_{2}$-eq/year

$151,524 \mathrm{~kg} \mathrm{CO}_{2}$-eq/year

$179,603 \mathrm{~kg} \mathrm{CO}$-eq/year

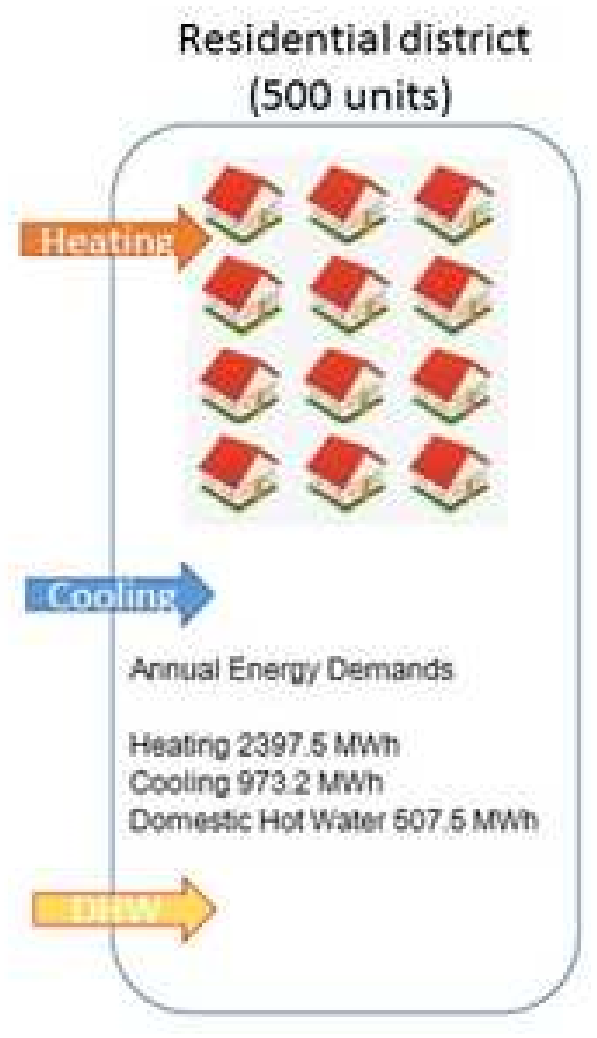

